\title{
Govorni izraz bijesa u hrvatskim filmskim komedijama
}

Aвstract: Vlašić Duić Jelena, Govorni izraz bijesa u hrvatskim filmskim komedijama (The Verbal Expression of Anger in Croatian Comedy Films). "Poznańskie Studia Slawistyczne" 9. Poznań 2015. Publishing House of the Poznań Society for the Advancement of the Arts and Sciences, pp. 395-410. ISSN 2084-3011.

The purpose of this paper was to examine the verbal expression of anger in Croatian comedy films and also to find textual and prosodic elements that provoke the viewer's exhilaration. On the textual level analysis includes elements with which anger causes exhilaration and shows that such anger most often expresses superiority and is also unexpected which often occurs as a result of exaggeration. Due to the specific genre of comedy, i.e. its guaranteed lack of seriousness, the viewers are not aware of high presence of anger in film comedies. Comedy requires a different insight to life situations and a reinterpretation that leads to pleasant emotions.

KeYwords: film dialogue; Croatian film; comedy; anger; exhilaration; prosody

\section{Specifičnost žanra komedije}

Budući da je velik dio filmskoga govora u funkciji ostvarivanja narativne uzročnosti (Kozloff 2000), u gledatelju se budi znatiželja i on se pita: Zašto?, Kako? ili Što će lik sada napraviti? Struktura rješavanja problema, tipična za klasične filmove fikcije, u potpunosti je kompatibilna s teorijom zadovoljstva prema kojoj je djelovanje povezano s očekivanjem i njegovim odgođenim ispunjenjem. Filmolog Dirk Eizten (1999) ističe da upravo stalnim postavljanjem novih pitanja, $\mathrm{tj}$. stalnim odgovorima i anticipacijama gledatelj biva zabavljen. Međutim, specifičnost je žanra komedije u tome što se struktura rješavanja problema iznevjeruje jer su za stvaranje komičnosti i humora upravo nužni nesklad - inkongruentnost i nepredvidljivost, a neočekivani odgovori koje gledatelj dobiva stvaraju humor.

Komedija kao igranofilmski žanr obuhvaća filmove koji su prevladavajuće humorni, što podrazumijeva stalnu prisutnost arhetipskih motiva 
igre, anarhičnoga nereda i rasapa normi te razotkrivanja nesavršenstva ljudske prirode (Kragić, Gilić 2003). U komedijama se vrlo često obrađuju ozbiljne teme na komičan način, a uloga je komičnih elemenata u tome da ometaju raspletanje priče. Kako je onda moguće da se humor, koji je sastavni dio mnogih filmova, uopće ne uklapa u obrazac rješavanja problema na kojemu počiva većina holivudskih filmova? Eitzen (1999: 91) odgovara da je to zato što prosječni filmski gledatelj želi dobiti ponajprije koncentrirane afektivne, emotivne odgovore, a ne narativnost per se. Većina gledatelja ne želi samo uživati u gledanju kako se problem rješava, nego želi jako emocionalno iskustvo: tugu, strah, uzbuđenje, sreću, smiješnu stranu neprikladnoga ponašanja.

\section{Razveseljenost i bijes u komedijama}

Nizozemski psiholog Ed S. Tan tvrdi da narativni film stvara u gledatelju iluziju da je on fizički prisutan u izmišljenom filmskom svijetu i da su emocije koje film u gledateljima izaziva prave, istinske emocije, iako su izazvane umjetnim poticanjem (Tan 1996: 2). Bijes je neugodna emocija, karakteriziraju je napetost i neprijateljstvo koji proizlaze iz frustracije, stvarne ili izmišljene povrede od strane drugoga ili od doživljene nepravde (VandenBos 2007: 53). Humor nije emocija, ali prisutan je u različitim formama, npr. šale, crtići, šaljive priče, parodije, pantomima, filmski žanr komedije itd. pouzdani izvori emocije koju psiholog Willibald Ruch (1993) naziva razveseljenost (engl. exhilaration; od lat. hilaris, veselo) i definira je kao proces stvaranja ili privremenog povećavanja veselja, tj. kao ugodno i opušteno uzbuđenje te kao aspekt pozitivne emocije sreće (ili radosti, veselja), a čvrsto je povezan sa smijehom.

Istraživanje o navikama gledanja filmova i doživljaju domaćega filma koje je potkraj 2013. godine proveo Hrvatski audiovizualni centar (HAVC) ${ }^{1}$ pokazalo je da Hrvati ne idu redovito u kino (češće filmove gledaju na televiziji), ali kada idu, obično gledaju komedije (Navike gledanja filmova i doživljaj domaćeg filma, 2013). Najboljim publika i dalje smatra

\footnotetext{
${ }^{1}$ HAVC je javna ustanova koja se bavi promicanjem audiovizualnoga stvaralaštva u Hrvatskoj.
} 
film Kreše Golika Tko pjeva zlo ne misli (1970)2, a slijedi ga šest filmova nastalih u posljednjem desetljeću 20. stoljeća filmovi: Vinka Brešana Kako je počeo rat na mom otoku, Maršal i Svećenikova djeca, potom film Hrvoja Hribara Što je muškarac bez brkova, Sonja i bik Vlatke Vorkapić, Metastaze Branka Schmidta. Svi su ti filmovi (osim Metastaza) komedije, što znači da Hrvati u kino najčešće odlaze kako bi se zabavili ili opustili. Iako čak i najnapetiji trileri imaju šaljivih trenutaka koji popravljaju raspoloženje ili imaju ulogu opuštanja gledatelja prije kakvoga sljedećeg napetog prizora, samo su u komedijama komični elementi u prvome planu, a govor u njima služi kao neka vrsta „komičnoga motora“ (Kozloff 2000: 54). U svim filmskim žanrovima može biti i neugodnih i ugodnih emocija, ali za razliku od horora u kojem glavni likovi izravno osjećaju strah, ili trilera u kojem se dominantno izražava tjeskoba pa su tjeskobni i glavni likovi, u komedijama se glavni likovi rijetko smiju i nisu baš razveseljeni, čak se može reći da i ne prevladavaju ugodne, nego dapače, neugodne emocije. Dojam da gledatelji te činjenice nisu svjesni potvrdila je anketa ${ }^{3}$ na uzorku od 18 ispitanika koji su trebali rangirati emocije: strah, radost, bijes, tugu i iznenađenje prema količini njihove izraženosti u filmskim komedijama (najmanje zastupljenu emociju ocjenom 1, pa redom do 5 za najviše zastupljenu). Ispitanici su odgovorili da je u komedijama najviše izražena radost (prosječna ocjena 4,5), a slijedi je iznenađenje $(4,2)$. Bijes $(2,6)$, strah $(2)$ i tuga $(1,4)$ dobili su znatno niže prosječne ocjene. Razloge dojma da je radost najzastupljenije izražena emocija treba tražiti u tome što, kako navodi hrvatski filmolog Hrvoje Turković, komedija podrazumijeva opušteno, nezabrinuto praćenje zbivanja i od ostalih se žanrova razlikuje po tome što su u njoj neozbiljnost, pa onda i razveseljenost „unaprijed zajamčene“ (Turković 2005: 13-40). Negativne emocije zaboravljamo, pa kao da i nisu prikazane jer ih nadvladaju pozitivne. Ipak, u komedijama ima i neugodnih emocija, ima bijesa i straha jer uostalom, čemu bismo se smijali ako bi svi likovi bili zadovoljni i radosni. Nakon što su pogledali jednu hrvatsku filmsku komediju, isti su ispitanici ponovno trebali rangirati emocije. Strah i tugu slično su, nisko ocijenili $(2,1$ i 2,4$)$,

\footnotetext{
${ }^{2}$ Taj je film u istraživanjima i anketama već više puta proglašen najboljim hrvatskim filmom svih vremena i po mišljenju kritičara i po mišljenju publike.

${ }^{3}$ Anketa je provedena na Odsjeku za fonetiku Filozofskoga fakulteta Sveučilišta u Zagrebu u ožujku 2014. Ispitanici su bili studenti 3. i 4. godine fonetike.
} 
kao i radost $(2,3)$. Nešto višu ocjenu dobilo je iznenađenje $(3,4)$, a najbolje je rangiran, tj. prema njihovu se mišljenju u komedijama najviše izražava - upravo bijes $(4,4)$.

O povezanosti humora i bijesa govore i sami komičari, primjerice, Lewis Niles Black (McClure 2013), američki komičar, pisac i glumac tvrdi da je najzabavniji kad je jako ljut i da njegove komedije nastaju upravo iz ljutnje. Poznat je po svojem ljutitom licu i izvedbe su mu prepune vikanja. U eseju o ženskom bijesu novinarka Suzanne Moore (2013) objašnjava da su ljudi često smiješni kad su ljuti, a američki pisac Stephen King (1998) kaže da je humor gotovo uvijek ,uljepšani, našminkani bijes“.

\section{Istraživanje: Govorni izraz bijesa u filmskim komedijama}

\subsection{Cilj istraživanja}

Temeljna su pitanja ovoga istraživanja: kakva je zastupljenost govornoga izraza bijesa u hrvatskim komedijama, kojim se govornim sredstvima taj bijes ostvaruje te čime govorni izraz bijesa izaziva humor, tj. razveseljenost gledatelja. Pretpostavka je da gledatelji nisu svjesni prisutnosti izraza bijesa zbog specifičnosti žanra komedije, tj. zbog njezine zajamčene neozbiljnosti.

\subsection{Materijal i metoda}

Istraživat će se govorni izraz bijesa u pet komedija koje su prema navedenome istraživanju HAVC-a među najboljim hrvatskim filmovima: Golikov Tko pjeva, zlo ne misli, Brešanovi: Kako je počeo rat na mom otoku, Svećenikova djeca, Hribarov Što je muškarac bez brkova te Sonja i bik V. Vorkapić ${ }^{4}$. U svakom je filmu izdvojeno po deset primjera govornoga izraza bijesa. Budući da su se u prethodnom istraživanju govornoga izraza

${ }^{4} \mathrm{U}$ tekstu će se nadalje koristiti sljedeće kratice za filmove: TP (Tko pjeva zlo ne misli), ŠM (Što je muškarac bez brkova), KP (Kako je počeo rat na mom otoku), SB (Sonja i bik), $\mathrm{SD}$ (Svećenikova djeca). 
emocija u hrvatskome filmu (Vlašić Duić 2013) već istraživali intenzitet, ton i tempo kao prozodijska sredstva karakteristična za izraze bijesa, u ovoj će se perceptivnoj analizi sloja glasa opisati i neki drugi prozodijski elementi, a prikaz intonacije u odabranim primjerima bijesa pomoću programa za akustičku analizu govora Praat (Boersma, Weenink 2009) poslužit će samo kao ilustracija. U sloju teksta proučit će se kojim se tekstualnim elementima u izrazima bijesa izaziva razveseljenost.

\subsection{Rezultati i rasprava}

Nije lako postići da se različitim gledateljima, s različitim emocionalnim pristupima probudi određena emocija. Neki su od izdvojenih govornih izraza/prizora bijesa kraći, neki duži (od 10 sekunda do 1,5 minute), u nekima je bijes izražajniji, jači, a u drugima je manje intenzivan i nije tako jako vruć i crven. Neki od tih izraza bijesa uopće ne nasmijavaju (prije navedeni bijes majora Alekse u Brešanovu filmu KP), a neki su govorni izrazi bijesa doista komični motori i često se nalaze na popisu najsmješnijih filmskih citata (Lucin bijesni monolog u filmu KP). Ipak, ni to im ne jamči da će baš svakoga nasmijati jer između komičnoga objekta i čovjeka koji se smije ne postoji nužna veza niti zakonitost. Humor(istič)na kompetencija stječe se odgojem i obrazovanjem, a razlike među ljudima su velike, pa će isti prizor u komediji jedne nasmijati i razveseliti, a druge će ostaviti ravnodušnima. Govor je spoj glasa i teksta, odnosno spoj posebnih govornih i jezičnih znakova koji se istodobno realiziraju, ali ti slojevi u govoru često nisu uravnoteženi, nego jedan od njih prevladava. Pri oblikovanju govora glumac će često svjesno dati prednost sad jednom, sad drugom govornom sloju. Da bi prevladao sloj glasa, moraju biti izražajniji prozodijski elementi, npr. intonacija, boja glasa, visina glasa itd. Budući da se glas i tekst istodobno realiziraju, gotovo je nemoguće odrediti količinu informacija što ih donose ta dva govorna sloja, pa su prijepori o važnosti, tj. većoj informativnosti glasa ili teksta uzaludni. 
Analiza teksta ${ }^{5}$ pokazuje da u svim proučenim primjerima bijesa prevladava konativna (zapovjedna, apelativna) funkcija, govor je usmjeren djelovanju na primatelja poruke, apelira na njegove osjećaje i misli, želi izazvati njegovu reakciju. Sredstva kojima se ostvaruje konativna funkcija su: vokativ, drugo lice jednine i množine te imperativ. Drugo lice često je dodatno naglašeno uporabom ličnih zamjenica $t i$ i vi, npr. „Ti si umorna? Što ti ne ležiš kad si umorna?" (SB) koje su govorno istaknute kao jezgre (rečeničnim naglascima). Rečenice su najčešće usklične, često kratke i eliptične. Vrlo su česte i upitne rečenice koje su većinom retorička pitanja u kojima se odgovor ne očekuje jer bijesan govornik i ne dopušta da mu se itko usprotivi. Takva su pitanja manipulativna i služe za izražavanje nadmoći, npr. „Šta je sad? Oćete mi reć da van ovo služi za blagoslov?” (SD). Riječi prijekora, prijetnje, pogrdne riječi i psovke također su česte u analiziranim govornim izrazima bijesa, kao i uporaba modifikatora kojima se pojačavaju pragmatički faktori komunikacije: pozornost, komunikacijska namjera (bijes) i stvaranje svađalačkoga odnosa među sugovornicima. Modifikatori služe za pojačavanje i naglašavanje pojedinih riječi u rečenici, a najčešće naglašavaju suprotnost, npr. ma i pa. Ana: „Ma kamo ćeš opet, tek smo došli, a ti već moraš lokati!” Franjo: „Prvo i prvo, ja u crkvu ne idem. A ak' si hoću popit gemišt, to je moja privatna stvar!” (TP). Upravo pragmemi kojima se izražava neslaganje sa sugovornikom upućuju na izravnu komunikaciju. Očekivano, budući da film teži realističnosti, sva su leksička i sintaktička sredstva emotivizacije karakteristična i za svakodnevne izraze bijesa i za izraze bijesa u drugim filmskim žanrovima, ni žanr komedije tu nije iznimka.

U jezično-komunikacijskom smislu analiziranim je govornim izrazima bijesa koji razveseljuje zajedničko to što i humor i bijes narušavaju Griceove (1991: 22-40) zakone kooperativnoga, suradljivoga komuniciranja: 1) princip kvantitete (često se govori više ili manje nego što je potrebno, preuveličavaju se ili umanjuju činjenice, misli i sl.); 2) princip kvalitete (ne govori se istina, govori se bez dokaza ili se izmišlja); 3) princip relevantnosti (govori se ono što nije relevantno, što se ne odnosi na temu o kojoj

${ }^{5}$ Tekstualni zapis koji se donosi nastao je slušanjem i bilježenjem govora ostvarenoga $\mathrm{u}$ filmovima. 
se komunicira, što nije za tu temu i kontekst važno); 4) način iznošenja obavijesti (česte su dvosmislenosti, ne govori se kratko i jasno).

U suvremenoj literaturi teorije humora najčešće se dijele u tri skupine: teorije inkongruentnosti, teorije olakšanja i teorije superiornosti (Morreall 1987; Smuts 2006; Critchley 2007). Prema teoriji inkongruentnosti humor proizlazi iz doživljaja nesklada, nepodudarnosti onoga što znamo ili očekujemo s onim što se uistinu dogodi. Toj skupini pripada i teorija Henrija Bergsona (1987) koja se temelji na etičkom neskladu. Bergson vidi smiješno u čovjekovoj mehaničkoj krutosti, kontrastnoj spram spretnosti i gipkosti koju bismo očekivali. Druga je skupina teorija humora najzastupljenija među psihoanalitičarima, a zasniva se na teoriji olakšanja: humor je način oslobađanja zatomljene (nervozne) energije, pa tako humor oslobađa od napetosti, inhibicija, konvencija, od ustaljenih odnosa u društvu. Prema teoriji superiornosti smijeh je stanje ,iznenadne slave”, pa i oholosti koju osoba osjeti kad shvati vlastitu nadmoć nad drugima, a naglašava se da su upravo agresivni osjećaji oni iz kojih humor crpi snagu. Inkongruentnost se zasniva na kognitivnom ili spoznajnom pristupu, olakšanje na afektivnom ili čuvstvenom, a superiornost na konativnom pristupu, tj. na isticanju nadmoći (Eysenck 1942).

Na osnovi Griceovih principa (točnije, oslobađanja od njih) i navedenih teorijskih pristupa humoru mogu se razlikovati tipovi humora (Horga 1996), a ovdje će se izdvojiti kategorije u koje se mogu svrstati analizirani primjeri bijesa koji razveseljuju. Duži primjeri bijesa često ne pripadaju samo jednoj, nego dvjema (rjeđe i trima) kategorijama.

\section{1) Nadmoć}

Među analiziranim primjerima razveseljavajućeg bijesa najviše je onih u kojima se bijesom izražava nadmoć nad sugovornikom (15 primjera). Zbog nemogućnosti vladanja situacijom, likovi često viču i prijete, ali ne dolazi do fizičke agresije. Najviše je takvih primjera superiornosti kojima se narušava temeljni Griceov princip idealne komunikacije pronađeno u filmu KP (6). U njima se potvrđuje ono što Bergson (1987: 11) naziva bezosjećajnošću ili „anestezijom srca” koja je, tvrdi, nužna za ostvarenje smiješnoga. Pritom je važno da šteta koju će taj bijes nanijeti nije velika jer će samo tada smijeh nadvladati suosjećanje. Nprimjer Aleksa je bijesan i viče na Roka i Murka koji ga pitaju mogu li obaviti nuždu: „Ne može! U ovoj kasarni nećete ni 
da pišate!" (KP). Nakon što je suprugu ulovio u preljubu, Franjo je ljut i ne vjeruje joj da se pokušala braniti, nego joj prijeti i tjera je od sebe: „Ja baš nisam videl da si se ti preveć branila. Ne dolazi mi više u blizinu. Među nama je svršeno. (...) I beži mi z očiju!” (TP). Postoje i primjeri u kojima nadmoć ima (ili bi mogla imati) za posljedicu neku veću štetu i u kojima je govornik agresivan, npr. Stipe, bivši vlasnik bika ljut je jer novi vlasnik hoće zaklati životinju (nakon što je izgubio u borbi), pa najprije viče, a i nasrće na njega: „Grkljan ću ti iščupat! Koga ćeš ti klat? (...) Pusti me, ubit ću ga!” (SB). Takvi govorni izrazi bijesa malo razveseljuju ili ne razveseljuju uopće, ovisno o tome očekuje li gledatelj da se takva prijetnja i ostvari.

\section{2) Neočekivan bijes}

Vrlo često razveseljenost izaziva i neočekivano izražavanje bijesa. Takvi izrazi također narušavaju princip idealne komunikacije, a bijes kao da je ničim izazvan, likovi odjednom, bezrazložno bivaju bijesni. U korpusu je pronađeno 14 takvih primjera bijesa (podjednakom se učestalošću javlja u svim filmovima). Vrlo je često povezan s otkrivanjem neke istine ili skrivene misli. Kad trafikant Petar čestita Juri na ženidbi s Vesnom, Jure mu uzvraća: „Mrš, j... se i ti i tvoji Tajvanci!” (SD). Gledatelj taj Jurin bijes reinterpretira, s obzirom na to da ima uvid u cijelu situaciju: Jure je ljut jer ne bi htio ženiti Vesnu, ali mora jer je trudna (on se štitio, a ne zna da je kondome trafikant Petar prethodno probušio). A kada je prije toga svećenik okupio trojicu potencijalnih očeva i održao im predavanje o tome kako kondomi nisu sigurna zaštita, to je potvrdio i jedan od njih, tvrdeći da je kupio kosilicu s Tajvana koja se pokvarila nakon tri dana (otuda Tajvanci, ali Petar ne zna zašto ih Jure spominje). U filmu KP vrhunac je napetosti u završnim scenama, kad vojnici s oružjem napuštaju kasarnu. Zbog Murkove majke koja je legla pred kamion, ta bi akcija mogla završiti tragično. Ne uspijevaju je uvjeriti da se makne, pa Murko, bijesan, nakon što sazna da mu je ostavila u nasljedstvo kuću i polje uzvikne vozaču: „Vozi! Gazi! Tuta forca!”. Nitko ne očekuje tako nešto. Majka se ipak digne i kamioni prođu.

\section{3) Pretjerivanje}

Likovi govore više ili manje nego što je potrebno; preuveličavaju ili umanjuju činjenice, misli itd. Ako gledatelj ima dojam da lik teško kontrolira bijes, da su njegovi izljevi bijesa pretjerani i da dopušta da bijes 
preuzme kontrolu nad njim, to biva smiješno. Najviše je takvih primjera bijesa pronađeno u najstarijem filmu iz korpusa (TP). Glavni lik, temperamentni malograđanin Franjo najčešće je ljut na suprugu, npr. zato što je darovala svoj šešir sestri, što mu prigovara da kasni, da previše pije, da nema glazbenoga ukusa itd. Čak pet analiziranih primjera iz filma TP pripada ovoj kategoriji, a od svih analiziranih primjera u svim filmovima u njih 13 se u izrazima bijesa pretjeruje. Bergson (1987) kaže da se smijeh javlja kao posljedica karikiranoga oponašanja, nefunkcionalnoga ponavljanja nekih kretnja i radnji. Franjino ponašanje (TP) doživljavamo kao karikirano i nefunkcionalno jer se ponavlja: vrlo je često bijesan, najbjesniji je od svih likova u analiziranim komedijama: „Ovo je tebi lepo pevanje? Hm, kajgod! Glupost! Ti šlageri uopće nisu nikakve pesme, neg' obično prenavljanje. Za to ne treba ni glasa ni sluha!" (supruzi koja uživa slušajući šlagere). U filmu SD Marta opravdava korištenje kondoma, a ljekarnik Marin (koji je nacionalist, rasist i ksenofob) suprotstavlja joj se: „Protuhrvatska politika! Ko, sida je problem? A to što hrvatski narod izumire, to nije problem?”.

\section{4) Otkrivanje skrivenih misli}

Neuzvraćenost bijesa, tj. mirnoća sugovornika kontrast je koji gledatelju pruža distancu i mogućnost uživljavanja u poziciju drugoga, neizazvanoga sudionika, kao i bržu reinterpretaciju. Kad stekne uvid u određenu situaciju u drukčijem svjetlu (a takav je uvid preduvjet i za smijeh), gledatelj shvaća da baš i nema razloga za bijes, pa ga to razveseljuje. U filmu KP majorova žena Luca treba nagovoriti muža da pusti vojnike i napusti kasarnu JNA. Obraća mu se s pozornice, govoreći svoj dugi monolog u mikrofon. Suprug Aleksa sluša taj njezin monolog iz kasarne, pa čak i kad bi htio ne može joj odgovoriti jer ga ona ne može čuti. Od početnoga mirnoga i nesigurnoga, emotivnoga obraćanja u kojem ga poziva da se preda, Lucin govor eskalira do bijesa i agresije kad sasvim neočekivano promijeni temu i otkrije nam svoje skrivene misli pa ga počinje okrivljavati za nevjeru te mu prijeti da će ga ostaviti i osvetiti se ljubavnici: „A znam ja di si ti bija! Bija si kod one ku..e! (...) Ma oči ću joj iskopati, jezik ću joj izrizati da više ne more s njim blejati” (KP). U većini dužih izraza bijesa razveseljenost izaziva neko neočekivano otkrivanje istine ili skrivene misli: u svađi Nike i Davora počinjemo se smijati tek kad Nika optuži Davora za perverziju, otkrivajući da on voli gledati pornografske filmove s tapirima (SB); 
$\mathrm{u}$ ispovijedi Tatjana don Stipanu prizna da je zaljubljena u njega, a on je osuđuje (iako isto osjeća i on prema njoj) te je šalje na ispovijed kod drugoga župnika, ali kada iznenada shvati da bi to Tatjanino priznanje moglo njemu naškoditi, pokušava je zaustaviti (ŠM); u Lucinu obraćanju Aleksi: najprije ga poziva da preda kasarnu, a onda se odjednom sjeti da ju je prevario (KP)... U devet analiziranih primjera bijes razveseljuje upravo takvim narušavanjem principa relevantnosti.

\section{5) Nesklad}

Kad likovi u svojem bijesnom izražavanju povezuju nešto što je općenito prihvaćeno da je nespojivo, rezultat je - razveseljenost. Takva se inkongruentnost javlja u sedam analiziranih primjera. Ivica telefonski objašnjava važnost dobre organizacije dočeka važnih političara: „Pa je l' znaš ti 'ko predvodi delegaciju? E pa ne znaš! Dođ' na doček, pa ćeš me razumit', Antičeviću! (...) Nemoj da pofali kapule!” (ŠM). Kad Stipu ne puštaju da $\mathrm{s}$ bikom Garonjom prijeđe granicu jer za bika nema ispravnu potvrdu, on se razbjesni: „A da imam kamion pun cigara, ne b(i) bilo problema!? Drš to! E jebemti granicu i koje je izmisli! Svi šverceri Hercegov(i)ne hodaju ovuda k’o da je korzo, a meni ne daš biku proć! Ajmo nazad!" (SB). U tim primjerima luk (kapula) i kamion pun cigara povezani su s organizacijom dočeka delegacije i s bikom, a takve neočekivane veze proizvode smijeh.

Iako se u analiziranom korpusu podjednako bijesni i muški i ženski likovi, različiti su razlozi njihova bijesa. Ženski likovi u svojim su izrazima bijesa najčešće razveseljuju time što neočekivano izražavaju svoje misli, stavove ili osjećaje i otkrivaju neke svoje skrivene misli, dok su muški najčešće smiješni jer pretjeruju ili zato što izražavaju svoju nadmoć nad sugovornikom. Vrlo su rijetki primjeri u kojima je istodobno bijesno više likova u prizoru (među analiziram ih je primjerima tek nekoliko). Najčešće je bijesan samo jedan lik, dok drugi pokušava smiriti situaciju. Razveseljenost izaziva to što se struktura rješavanja problema iznevjeruje jer likovi naprave nešto što gledatelj ne očekuje, što je u neskladu ili je nepredvidljivo. Kad dobije uvid u cjelokupnu situaciju, gledatelj integrira različite elemente, reinterpretira ih, objektivizira i to ga bijesu unatoč (i zahvaljujući) - razveseljuje.

Već je spomenuto da ima primjera bijesa (pronađeno ih je šest) koji se ne mogu svrstati u navedene skupine jer ne razveseljuju. Takav je primjer 
Aleksina bijesa prije ubojstva pjesnika Dantea (KP), a izostanak razveseljenosti uzrokuje upravo nemogućnost anestezije srca jer je posljedica Aleksina bijesa kobna (smrtna). U ostalim filmovima nema sličnih primjera crnoga humora pa ni sličnoga bijesa, ali ima primjera bijesa koji ne razveseljuju. U njima je bijes najčešće tek izraz nemoći i povrijeđenosti, npr. kad u filmu SB otac zapovijeda Anti da ode po Sonju, on mu se suprotstavlja: „Ćaća, o čemu pričaš? Di ću ić? Po koga ću ić?”. Antina je ljutnja opravdana (otac ne zna ni kako se ona točno zove, ni gdje živi). U filmu SD don Stipan se obraća Petru, kritizirajući ideju da Petar i Marta (koja već glumi lažnu trudnicu) uzmu ostavljeno dijete i da mještanima kažu da su mu oni roditelji. „Ne, vi ste potpuno poludjeli! (...) Ali ona ima trbuh kao da je u šestom mjesecu”. Kad u istom filmu Marin donese oružje za samoobranu, za slučaj da se zapuca, don Stipan će bijesno reći: „Ne, Marine. Ne. (...) Marine, molim te. Bez oružja!”. Ni veći dio vrlo realistične kakofonije, svađe Davora i Nike (SB) nije u funkciji razveseljavanja (sve do spominjanja Davorova fetiša). U svim tim primjerima bijesa gledatelj se može složiti s onim tko taj bijes izražava, prikazana reakcija je očekivana i nema kontradikcije, pa ni reinterpretacije, kao ni iznenadnoga razumijevanja, karakterističnoga za primjere bijesa koji razveseljava.

\subsubsection{BIJES U GLASU}

U analiziranim primjerima govornoga izraza bijesa pokazuje se da, u usporedbi s neutralnim govorom, prevladavaju sljedeća prozodijska sredstva: visok ton, jak intenzitet i brz tempo. To je podudarno i s prethodnom perceptivnom i akustičkom analizom govornoga izraza bijesa u filmskome govoru (Vlašić Duić 2013: 115-153), u kojem su iz 11 hrvatskih filmova odabrani slušni ulomci s izrazima bijesa, straha, radosti, tuge te izrazi bez emocije. Međutim, za razliku od toga istraživanja u kojem su odabrani samo oni slušni ulomci koje su prethodno ispitanici procijenili kao izraze s jakim intenzitetom emocije (npr. jak, vruć i crven bijes), u ovome istraživanju nisu analizirani samo primjeri jakoga bijesa, nego ima i primjera slabijega bijesa koji je ostvaren niskim tonom i manjim tonskim rasponom bez pojačanja intenziteta (npr. pregovori s majorom Aleksom oko predaje kasarne, KP). Različitost prozodijskih postupaka u ostvarenju vrućega i hladnoga bijesa (engl. hot/cold anger) navodi se u više studija, pa Tom 
Johnstone i Klaus R. Scherer (2004: 226-227) zaključuju da je za hladni bijes karakterističan izostanak velikoga variranja tona i povišenja fundamentalne frekvencije $\left(\mathrm{F}_{0}\right)$, a rezultati različitih akustičkih i perceptivnih istraživanja pokazuju da su za bijes karakteristična i druga prozodijska obilježja (npr. laringalna napetost, opor glas) ${ }^{6}$.

U ovome istraživanju ima i primjera jakoga bijesa koji se izriču slabim intenzitetom jer likovi ne žele da ih se čuje, pa šapću i govore sporijim tempom (npr. razgovor za vrijeme pogreba u SD; Tatjana na ispovijedi kod don Stipana u ŠM; Rokov i Murkov komentar za vrijeme Lucina monologa u KP). Govorni izrazi bijesa ostvareni niskim tonom, srednjim tempom i vrlo jakim izgovorom konsonanata uz prigušene vokale zvuče kao siktanje (Aleksa u razgovoru s Rokom u KP; ljekarnik Martin i don Stipan u SD). Suprotno tome, ima primjera u kojima se bijes prenosi vikanjem: preglasnim izgovorom vokala uz slabe konsonante, npr. svađa Fulira i Franje oko pjevanja (TP) ili bijesna Ljubica koja pregovara oko odštete koju bi trebala dobiti njezina sestra nakon smrti muža na njemačkom gradilištu (ŠM): „Ovo ni skinila nije (pokazuje na vjenčanicu) kad je stiga vami u Frankfurt. A sad ste joj kapu donili. Cvancih tauzand? Malo morgen!” (Slika 1).

Akustička analiza napravljena je u programu Praat (Boersma, Weenink 2009) i prikazana je u polutonovima (12 polutonova čini jednu oktavu; jedan poluton iznosi oko $6 \%$ promjene fundamentalne frekvencije $-\mathrm{F}_{0}$ ). Referentni ton (nula na ordinati) je $100 \mathrm{~Hz}(1$ poluton $=106 \mathrm{~Hz}, 2$ polutona $=112 \mathrm{~Hz} \ldots 12=200,24=400$ itd.). Skokovit ton prisutan je u svim rečenicama, a bijes kulminira u posljednjoj rečenici koja je ostvarena vikanjem i u kojoj su promjene tona najizraženije. Ukupan raspon tona iznosi čak 9 polutonova $(123-277 \mathrm{~Hz})$.

Međutim, česti su i primjeri u kojima se kombiniraju siktanje i vikanje te oni u kojima se vrući bijes ne ostvaruje skokovitim promjenama tona. Nprimjer već spomenuti Franjin (TP) izraz bijesa upućen supruzi nakon

${ }^{6}$ Istraživači uglavnom ne navode o kakvoj je vrsti bijesa riječ, a rezultati (provedenim u različitim jezicima) pokazuju da je za bijes karakterističan: nizak ton; jak intenzitet (Vuletić 2007); visok ton i velik raspon; neki slogovi ostvareni jačim intenzitetom; konsonanti se jako zatvaraju, a vokali otvaraju; velika laringalna napetost (Williams i Stevens prema: Vuletić 2007); velika laringalna napetost, jak intenzitet, opor glas (Bezooyen 1984); povišen ton uz skokovite promjene; pojačan intenzitet; ubrzan tempo (Scherer 2003); visok ton i velik tonski raspon; jak intenzitet; brz tempo (Jovičić, Kašić, Đorđević, Vojnović, Rajković, Savković 2003). 




Time (s)

Ovo ni skinila nije... A A sad ste joj... Cvancih...

Slika 1. Intonacija u govornom izrazu bijesa; Ljubica (ŠM)

što ju je zatekao s ljubavnikom, kad joj govori da je među njima svršeno i da joj neće oprostiti nevjeru. Ana: „Ali, tata... Franjo: Ništa, tata! Neću se rastavljati radi deteta, ali za tebe k'o da smo rastavljeni. I beži mi z očiju!". U drugoj rečenici Franjo pojačava izgovor vokala, dok u posljednjoj rečenici zatvara čeljusni kut, djelomično fiksira donju čeljust i govori kroz stisnute zube (Slika 2).

$\mathrm{Na}$ samom su početku prve rečenice prisutni jak početni udar i visok ton. U drugoj je rečenici tonski raspon vrlo velik, promjene tone su vrlo skokovite, a ukupni raspon iznosi čitavu jednu oktavu, čak 12 polutonova (78-283Hz). I u ovome primjeru bijes kulminira, tj. najvrući je u posljednjoj rečenici, ali je ona izgovorena kroz stisnute zube i s vrlo malim tonskim rasponom koji iznosi manje od 2 polutona $(137-170 \mathrm{~Hz})$.

Za prepoznavanje govornoga izraza bijesa trebalo bi detaljnije analizirati akustička obilježja na razini kraćih segmenata (kraćih od rečenice) i na koartikulacijskoj razini, a to je ono što se perceptivno opisuje kao: govorenje kroz zube, napeto, staccato i sl. te analizirati ono što je u ovoj analizi perceptivno uočeno kao isticanje pojedinih slogova jačom glasnoćom te velikom laringalnom napetošću (napetim glasom). Dakako, emocije u filmu ne ostvaruju se samo govorom, nego i drugim zvukovima (glazbom, 




Ništa, tata! Neću se rastavljati... I beži mi z očiju!

Slika 2. Intonacija u govornome izrazu bijesa; Franjo (TP)

šumovima i sl.) te vizualnim (mimikom, gestama itd.) i drugim filmskim sredstvima, ali se u ovome radu ta sredstva nisu istraživala.

\section{Zaključak}

Pokazalo se da je mnogo govornih izraza bijesa u hrvatskim komedijama i da je to zato što je bijes pogodan za reinterpretaciju. U govornim izrazima bijesa koriste se tekstualna i prozodijska sredstva emotivizacije koja su karakteristična i za svakodnevne izraze bijesa, a u primjerima govornih izraza bijesa koji razveseljavaju najčešće se izražava nadmoć, neočekivan bijes ili se pretjeruje. Razlog zbog kojeg gledatelji nisu svjesni da u komediji ima mnogo izražene emocije bijesa leži u samome kontekstu komedije, tj. u specifičnosti njezina žanra jer komedija zahtijeva drukčiji uvid u životne situacije, zahtijeva reinterpretaciju. Gledatelji koji kupuju ulaznicu da bi pogledali komediju svjesni su da je ta reinterpretacija sadržana u cijeni, tj. da će dobiti neozbiljnost, dobro raspoloženje, razveseljenost. Zato i izraze neugodne emocije - bijesa, iako su ostvareni istim govornim sredstvima kojima se ostvaruju i u zbilji, ipak ne doživljavaju 
neugodnima, nego ih oni razveseljuju. I upravo je oslobađajuće to što se zbog razveseljenosti koju su izazvale, primjerice nečija nesreća ili bijes, gledatelj neće osramotiti, što njegova razveseljenost nije uvredljiva jer je to „samo film”. Ipak, zbog svoje se neozbiljnosti komedija tretira kao „kulturno neprestižan žanr“ (Turković 2005: 13-40), a ozbiljna (visoka) umjetnost, npr. žanr psihološke drame svoj status najvišega društvenog ideala u suvremenoj civilizaciji potvrđuje upravo kontrastiranjem prema zabavljačkoj umjetnosti - prema komediji. Suprotno tomu, zabavljačka umjetnost ne teži negativnom određenju ozbiljne umjetnosti, nego je ili zanemaruje kao nevažnu ili je čak integrira u sebe. Dakako, nepravedno je to što visoka umjetnost ima unaprijed zagarantiran visok i uzoran, društveno vrednovan status jer svaka djelatnost koja potiče maštu (dakle i zabavna), bez obzira na društveni status, ,ima mogućnost za najviše percepcijske dosege" (Turković 2005: 13-40). Kao gledatelji, mi rezoniramo s onim što se događa na platnu: radujemo se s likovima koji uspijevaju riješiti probleme, osjećamo zadovoljstvo, sreću i razveseljenost, emocije koje nas jačaju. Zato sve te karakteristike žanra komedije: sretan kraj, rješivost sukoba, nagrada dobrima, a kazna zlima, obrat i oprost, baš kao i bijes koji razveseljuje, afirmiraju temeljne društvene vrijednosti.

\section{Literatura}

Bergson H., 1987, Smijeh. Esej o značenju komičnog, prev. B. Brlečić, Zagreb.

Boersma P., Weenink D., 2009, Praat: doing phonetics by computer, (Computer program, version 5.1), <www.praat.org>, 15.02.2014.

Critchley S., 2007, O humoru, prev. D. Vulić-Budanko, Zagreb.

Eitzen D., 1999, The Emotional Basis of Film Comedy, u: Passionate Views: Film, Cognition, and Emotion, ur. C. Plantiga, G.M. Smith, Baltimore-London, str. 84-99.

Eysenck H.J., 1942, The Appreciation of Humour: An Experimental and Theoretical Study, ,The British Journal of Psychology” br. 32/4, str. 295-309.

Grice P., 1991, Studies in the way of words, London.

Horga D., 1996, Humor u javnim elektroničkim medijima, u: Jezik i komunikacija: zbornik radova, Zagreb, str. 70-77.

Johnstone T., Scherer K.R., 2004, Vocal Communication of Emotion, u: Handbook of Emotions, ur. M. Lewis, J.M. Haviland-Jones, New York-London, str. 220-235.

Jovičić S.T., Kašić Z., Đorđević M., Vojnović M., Rajković M., Savković J., 2003, Formiranje korpusa govorne ekspresije emocija i stavova u srpskom jeziku - GEES, $<$ http://www.telfor.rs/telfor2003/radovi/7-10.pdf $>$, 18.12.2014. 
King S., 1998, Bag of bones, <http://www.goodreads.com/quotes/24733-humor-isalmost-always-anger-with-its-make-up-on>, 15.12.2013.

Kozloff S., 2000, Overhearing film dialogue, Berkley-Los Angeles-London.

Kragić B., Gilić N. (ur.), 2003, Hrvatski filmski leksikon, Zagreb.

McClure K., 2013, The Root of All Anger: Comedian Lewis Black speaks softly about yelling (intervju s L.N. Blackom), <http://www.riverfronttimes.com/2013-10-03/ music/lewis-black-the-rant-is-due-comedy-peabody-opera-house/>, 20.01.2014.

Moore S., 2013, Seeing red: the power of female anger, <http://www.newstatesman. $\mathrm{com} /$ politics/2013/01/seeing-red-power-female-anger>, 15.01.2014.

Morreall J., 1987, The philosophy of laughter and humor, New York.

Navike gledanja filmova i doživljaj domaćeg filma, 2013, „Hrvatski filmski ljetopis” br. 76, istraživački projekt, str. 49-63.

Ruch E., 1993, Exhilaration and Humor, u: The Handbook of Emotion, ur. M. Lewis, J.M. Haviland, New York, str. 605-616.

Scherer K.R., 2003, Vocal communication of emotion: a reiview of research paradigms, „Speech communication” br. 40, str. 227-256.

Smuts A., 2006, Humor, u: International Encyclopedia of Philosophy, <http://www. iep.utim.edu/humor/>, 1.02.2014.

Šošić A., 2009, Film i rat u Hrvatskoj. Refleksije jugoslavenskih ratova u hrvatskom igranom filmu (intervju s H. Turkovićem), „Zapis, bilten Hrvatskog filmskog saveza" br. 64/65, <http://www.hfs.hr/nakladnistvo zapis detail.aspx?sif_clan$\mathrm{ci}=32575 \# . U 33 \mathrm{nM} 3 \mathrm{aE6B} 8>$, 1.02.2014.

Tan E.S., 1996, Emotion and the structure of narrative film: film as an emotion machine, New Jersey.

Turković H., 2005, Film: zabava, žanr, stil, Zagreb.

Van Bezooyen R., 1984, Characteristics and Recognizability of Vocal Expressions of Emotion, Dordrecht-Cinnaminson.

VandenBos G.R. (ur.), 2007, APA Dictionary of Psychology, Washington.

Vlašić Duić J., 2013, U Abesiniju za fonetičara: govor u hrvatskome filmu, Zagreb.

Vuletić B., 2007, Lingvistika govora, Zagreb.

\section{Filmografija}

Kako je počeo rat na mom otoku, 1996, r. V. Brešan.

Sonja i bik, 2012, r. V. Vorkapić.

Svećenikova djeca, 2013, r. V. Brešan.

Što je muškarac bez brkova, 2005, r. H. Hribar.

Tko pjeva zlo ne misli, 1970, r. K. Golik. 